$$
\operatorname{cin} 8-910.4193--2
$$

UCRL-JC-107830

PREPRINT

jut 2 \& 399

\title{
DESIGN FOR CONTAINMENT OF HAZARDOUS MATERIALS
}

\author{
Robert C. Murray \\ Lawrence Livermore National Laboxatory \\ James $\mathrm{R}$. McDonald \\ Texas Tech University
}

This paper was prepared for submittal to the Tornado Symposiun III Norman, Oklahoma

April 2-5, 1991

\section{March 1991}

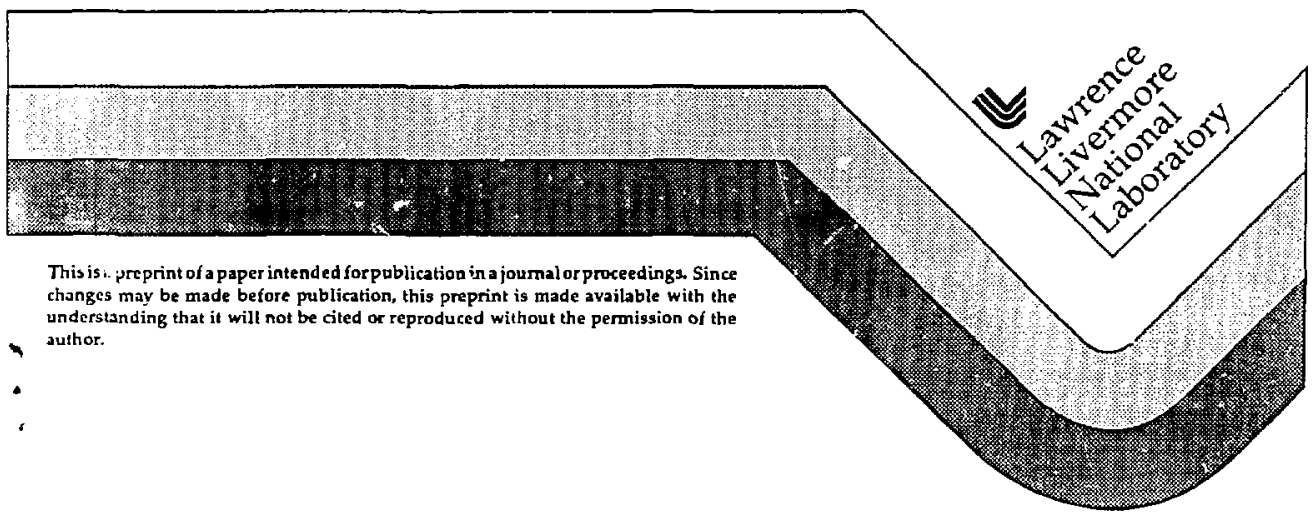




\section{DISCI,AIMER}

This docament was prepared as an account of work spontsored by an aperisy of the United Sinteg Govemment. Neilber the United Stalea Gorernment nor the University of Californie nor any of their employect, mukes any warranty, express of Implied, or assumex any legat liability or responsibility for the accuracy, completeness, or uscfulness of any information, apparanus, product, or process disclosed, or repres ats that its use would nol infringe privalely owned rights. Reference herein lo any specilic commercial products. process, or service by trade name, tradenark, manufacturer, or

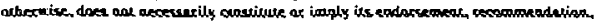
of favoring by the United States Government or the University of California. The riens and opinions of authors expressed herein do brot necessurily stale or reflect those of the Uniled States Goremment or the Unirersity of California, and shall not be used tor uirertising or produd endorsement purposes. 


\section{Design for Containment of Hazardous Materials}

UCRL-JC- -107830

DE.91 015762

\begin{abstract}
Department of Energy. (DUE), facilities across the Urited States, use wind and tornado design and evaluation criteria based on probabilistic perfuimance goais. In addition, cther programs such as Advanced Light Water Reactors, New Production Reaciors, and Individual Plant Examınations for External Events for commercial nuclear power plants utitize oesign and evaluation criteria based on probabilistic pertormance geals. The use of probabilistic pertormance goals is a cepanure trom design practice for commercial nuclear power planis which have traditionally been designed utlizing 3 conservative specification of wind and tornado toaoing combined with deterministic response evaluation meinoas and permissible behavior limits. Approaches which utilize prodabilistic wind and tornado hazard curves for specification of loading and deterministic response avaluation melhods and permissible behavior limits are discussed in this paper. Through the use of such design/evaluation approaches, it may be demonstrated that there is nign likelihcod that probabilistic performance goals can be achieved.
\end{abstract}

\section{Introduction}

Use of deterministic design and evaluation criteria to meet probabilistic performance goals is the approach used by DOE facilities across the United States as given in UCAL-15910. "Design and Evaluation Guidelines for Department oi Energy Facilities Subjected to Natural Phenomena Hazards". (Kennedy, et al. 1990). An overview of the approach is presented in this paper.

In this paper, three types of winds are discussed: extreme (straight), humcane, and tornado. Extreme (straight) winds are non-rotaling such as those found in thunderstorm gusi fronts. Wind circulating around high or low pressure systems are rotational in a global sense, but they are considered "straight" winds in the context of this paper. Tornadoes and hurricanes both have rotating winds. The diameter of rotating winds in a small hurncane is considerably larger than the diameter of a large tornado. However, most tornado diameters are relatively large compared to the dimensions of typical buildings. It is estimated that the diameter of 80 percent of all tornadoes is greater than 300 feet.

Wind pressures produced by extreme winds are studied in Doundary layer wind tuinnels. The results are generally considered reliable because they have been veritied by selected full-scale measurements. Investigations of damage produced by extreme winds tond to support the wind tunnel findings. Aithough the rotating nature of hurricane and tornado winds cannot easily be duplicated in a wind tunnel, damage investigations suggest that pressures produced on enctosed buildings and other structures by extreme. hurricane, and tornado winds are so similar that it is almost imipossible to look at damage to an individual structure and tell which type of wind produced it. Thus, the approach for determining wind pressures on buildings and other stnuctures proposed in this paper is considered io be independent of the lype of windstorm. The recommended procedure is essentially the same for straight, hurricane, and tornado winds.

UCRL-15910 wind and tornado provisions use deterministic evaluation criteria with the hazard annual probability of exceedance specified $10 \mathrm{get}$ design/evaluation wind speeds. The evaluation of response and structure or equipment capacities are performed using deterministic methods which are tamiliar to engineers. Wind speeds are developed fromi probabilistic hazard curves are used to meet performance goals for various building occupancies.

\section{Performance Goals}

Performance goals may be expressed in terms of annual probability of exceedance of some tevel of damage. Levels of damage can include that damage beyond which occupants are endangered, beyond which hazardous materials cannot be contined, beyond which a tacility cannot sately shutdown, or beyond which a facility cannot continue its mission. The pertormance goal for the salety of Advanced Light Water Reactors is on the order of $1.0 \times 10^{-5}$ annual probability of exceedance for external events induced core damage, (EPRI, 1990). Performance goals upon which designevaluation guicelines are based tor $\mathrm{OOE}$ facilities in UCRL-15910, are presented in Table 1.

\section{- Lawrence Livermore National Laboratory}

Livermore, Californı

- Texas Tech Universiry

Lubbock, Texas

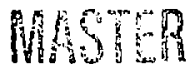

DISTRIBUTION OF THIS DOCUMENT IS UNLIMITED 


\begin{tabular}{|c|c|c|}
\hline $\begin{array}{l}\text { Usage } \\
\text { Category }\end{array}$ & $\begin{array}{l}\text { Pertomance Goal } \\
\text { Descrotion }\end{array}$ & $\begin{array}{l}\text { Performance Goal } \\
\text { (Annual Probability } \\
\text { of Exceedance) }\end{array}$ \\
\hline $\begin{array}{c}\text { General } \\
\text { Use }\end{array}$ & Maintain Occupant Safery & $\begin{array}{l}-10^{-3} \text { of the onset of major component da nage to } \\
\text { the extent that occupants are endangered }\end{array}$ \\
\hline $\begin{array}{l}\text { Important or } \\
\text { Low Hazard }\end{array}$ & $\begin{array}{l}\text { Occupant Satety, Continued Operation } \\
\text { with Minimal Intermption }\end{array}$ & $\begin{array}{l}-5 \times 10^{-4} \text { of component damage to the extent that } \\
\text { the component cannot pertorm its function }\end{array}$ \\
\hline $\begin{array}{l}\text { Moderate } \\
\text { Hazard }\end{array}$ & $\begin{array}{l}\text { Occupant Satety, Cantinued Function, } \\
\text { Confinement }\end{array}$ & $\begin{array}{l}-10^{.4} \text { of component damage to the extent that the } \\
\text { component cannot pertom its function }\end{array}$ \\
\hline $\begin{array}{l}\text { High } \\
\text { Hazard }\end{array}$ & $\begin{array}{l}\text { Occupani Safety, Continued Function } \\
\text { Very High Confidence of Conlinement }\end{array}$ & $\begin{array}{l}-10^{-5} \text { of component damage to the axtent that the } \\
\text { component cannot pertorm ts tunction }\end{array}$ \\
\hline $\begin{array}{l}\text { Cormmercial } \\
\text { Reactor }\end{array}$ & \multicolumn{2}{|c|}{ Beyond the scope of UCAL-15910 } \\
\hline
\end{tabular}

11 Component refers to structure, equipment, or distribution system.

Table 1. Performance Goals for Each Usage Category

For each performance goal there are separate wind and cornado design and evaluation criteria. DOE management categorize facilities or individual structures, systems, or components depending on the cost, mission importance, or hazard to people or the environment. For UCRL-15910, a DOE natural phenomena hazards panel selected reasonable and achievable penormance goals, bounded by current practice.

- For ordinary facilities, the pertormance goals are consistent with design according to conventional building code provisions.

- For high hazard facilities, the performance goals are comparable 10 performance reached by nuclear power plants as measured by probabilistic risk assessments (PRAs).

\section{Performance Goal Achievement}

Structure/equipment performance is a function of: (1) the likelihood of hazard occurrence and (2) the strength of the structure or equipment item. Theretore, design and evaluation criteria have been developed to attain pertormance goals by: (1) specification of hazard probability tor definition of wind and tornado loadings and (2; specification of response evaluation methods, acceptance criteria. and design

\footnotetext{
Note inat UCRL-15910 periormance goals are relajed to indrvidual component benavior while PAA resuls are in rams of core damege.
}

detailing requirements with controlled levels of conservatism. Acceptable performance can only be achieved by consistent specification of all design or evaluation criteria elements as shown below:

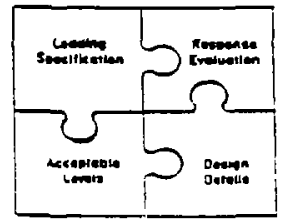

UCAL-15910 wind and tornado design and evaluation guidelines contain the following provisjons:

\section{Lateral Force Provisions}

Damage Control Provisions

Detailing Provisions

Quality Assurance and Peer Review Provisions

Windhornado performance depends on the level of the hazard and on conservatism in the response evaluation and acceptance criteria. For example, $\approx$ performance goal of $1 \times 10^{-4}$ can be achieved either by: (1) a conservative evaluation/acceptance approach for a more frequent hazard orobability, such as $1 \times 10^{-3}$ or by: (2) a median centered evaluation/acceptance approach coupled with a less trequent $1 \times 10^{-4}$ hazard 
probability. UCRL-15910 uses the former approach vecause conservative evaluation/acceptance approaches are well established, extensively cocumenied. and commoniy practiced.

\section{Design and Evaluation Criteria for Wind Load}

A uniform approach to wind load determination that is applicabie to the design of new tacilities and the evaluation of existing facilities has been developed for DOE. A uniform treatment of wind loads is recommended to accommodate extreme, hurricane, and tornado winds. Buildings or facilities are tirst assigned appropriate usage categories. Criteria are recommended such that the performance goals for eacin category can te achieved. Procedures according 10 ASCE 7-88 (formerly ANSI A58.1) (ASCE. 1990), are recommended for determining wind loads produced by straight, hurncane. and tornado winds. The extreme wind/tornado hazard models ceveloped lor DOE sites were used to establish site-specitic criteria for each of some 25 DOE sites, (Cuats and Murray, 1985).

The pertormance goals established for General Use and Important or Low Hazard usage categories are met by conventional building codes or standards, see (1C80, 1988). These criteria do not account for the possibility of tornado winds, because wind speeds associated with extreme winds typically are greater than those for tornadoes at exceedance probabilities greater than approximately $1 \times 10^{-4}$. For this reason. iornado design criteria are specitied only for buildings and tacilities in Moderate and High Hazard categories, where hazard exceedance probabilities are less than $1 \times 10^{-4}$

The traditional approach for establishing tornado design critena is to select extremely low exceedance probabilities. For example. the exceedance probasility for design of commercial nuclear power plants is $1 \times 10^{-7}$. NRC, 1974; Kimura and Budnitz, 1987; and Favindra. 1990). There are reasons for departing from this traditional approach. The low exceedance value for commercial nuclear power plants was established circa 1960 when very little was known about tornadoes trom an engineenng perspestive. Much has been learned about tornadoes since that time. Use of a low hazard probability is inconsistent with the practice relating to other natural hazards, such as earthquakes. There are many uncenainties in 1ornado hazard probability assessment. but they are not significantly greater Ihan :he uncertainties in earthquake probability assessment. The strongest argument against using low probability criteria is that a relatively short period of record ( 40 years) must be extrapolated to extremely small exceedance probabilities. For these reasons, an atternative approach was used in the

UCRL -15910 guidelines.

\section{a. Establishment of Wind and Tornado Hazard Annual Probabilities}

The rationale for establishing lornado criteria is described below. Figure 1 shows the tornado and straight wind hazard curves to: two DOE sites (SLAC and ORNL). The wind speed at the intersection of the tornado and straight wind curves is defined for purposes of this discussion as the transition wind speed. An exceedance probability is associated with each transition wind speed. If the exceedance probability of the transition wind speed is less than $1 \times 10^{-5}$ per year, tomadoes are not a viable threat to the site, because straight wind speeds are nigher tran tornadoes for a given return period. Thus. tronı figure 1, tornadoes need not be corisidered at SLAC, but should be considered at ORNL.

Mean wind and tornado hazard curves were developed for each DOE site. along with the transition wind speed. Those sites with transition wind speed exceedance probabilities greater than $10^{-5}$ should be designed for tornadoes; others should be designed for extreme winds or hurricanes.

The tomado wind speed is obtained by selecting the wind speed associated with an exceedance probability of $2 \times 10^{-5}$ per year. The value of $2 \times 10^{-5}$ is the largest one that can be used and still represent a point on the tornado hazard curvc. For example, the tornado wind speed for the ORNL is $130 \mathrm{mph}$ (peak gust at $10 \mathrm{~m}$ ).

A comparison of the slopes of the tornado hazard curves for the DOE sites reveals that the slopes are essentially the same even though the transition wind speeds are different. The criteria required to meet the performance goals of Moderate and High Hazard facilities can be met by using multipliers that are equivalent to an importance factor in the ASCE 7-88 design procedure. The muthipliers are specified in thes of two different exceedance probabilities for Moderate and High Hazard facilities. The value of the imponance factor is selected to achieve lower probability of tornado damage for Hign Hazard facilities compared to Moderate Hazard facilities. The importance factors are then chosen to meet the performance goals.

In general, design criterla for each usage category include:

1. Annual hazard exceedance probability.

2. Importance factor

3. Wind generated missile parameters for Moderate and High Hazard tacilities.

4 Tomado parameters for Moderate and High Hazard lacilities, if applicable. 


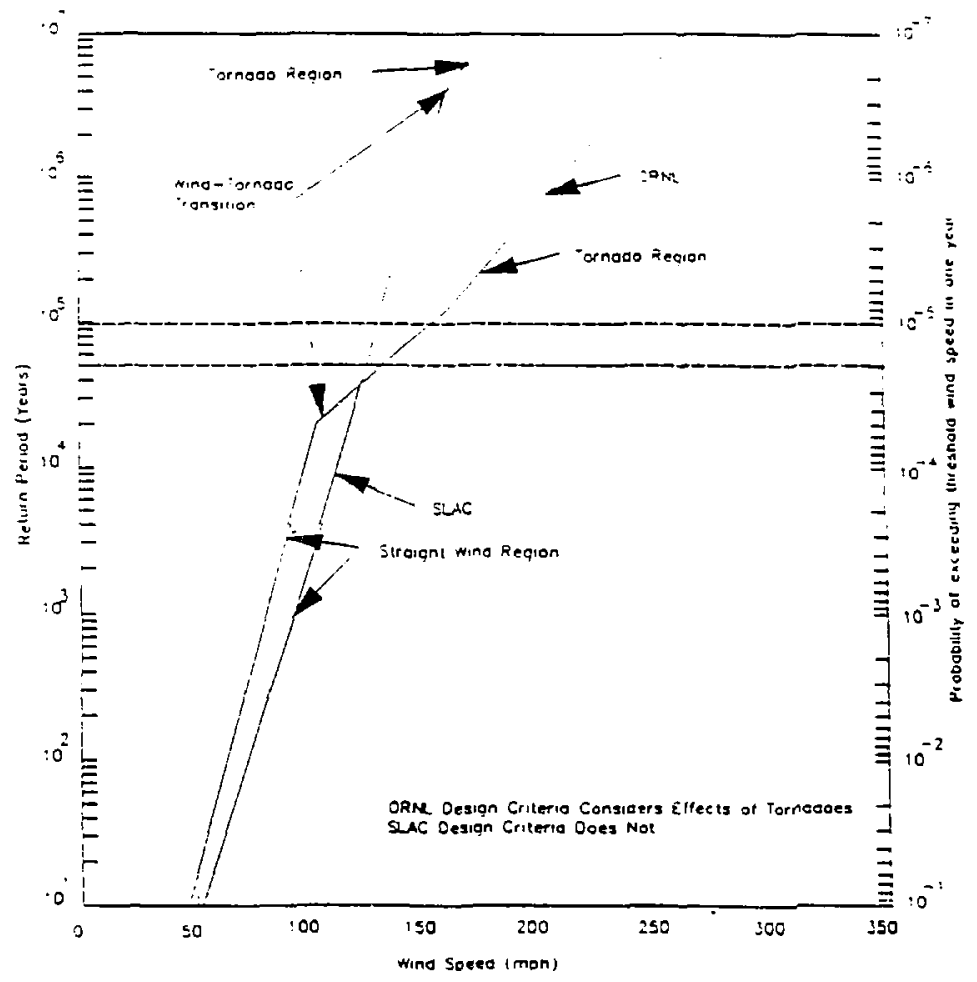

Figure 1. Straight Wind and Tomado Regions of Wind Hazard Curves

The criteria are formulated in such a way that a unifom approach for determining design wind loads, per ASCE 7-88, can be used for extreme, huricane, and tornado winds.

in order 10 apply the ASCE 7-88 procedure, tornado gusi wind speeds musi be converted to fastest-mile speeds. Appropriate gust response factors and velocity pressure exposure coefficients are utilized in the process of determining wind loads. Appropnate exposure categones atso are considered in the wind load calcuiations. Open terral: (Exposure C) should arways be assumed for tornado winds, regardless of the actuat terrain conditions.

\section{b. Criteria for Design of Facilities}

The criteria presented herein are consistent with the pertormance goals described earlier. Buildings or facilities in each category have a different role and represent ditterent leveis of hazard to people and the environment. In addition, the degree of wind hazard varies geographicaily. Facilities in the same usage category, but at different geographical locations. will have different input loading specified to achieve the same performance goal.

The minimum wind design criteria tor each of the four usage categories are summarized in Table 2. The recommended basic wind speeuss for extreme wind. 


\begin{tabular}{|c|c|c|c|c|c|}
\hline & 8uilding Category & General Use & $\begin{array}{l}\text { Important or } \\
\text { Low Hazard }\end{array}$ & Moderate Hazard & High Hazard \\
\hline \multirow{3}{*}{$\begin{array}{c}w \\
i \\
n \\
d\end{array}$} & $\begin{array}{c}\text { Annual Probability } \\
\text { of Exceodance }\end{array}$ & $2 \times 10^{2}$ & $2 \times 10^{-2}$ & $1 \times 10^{-3}$ & $1 \times 10^{4}$ \\
\hline & $\begin{array}{l}\text { Importance } \\
\text { Factor }\end{array}$ & $\begin{array}{c}1.0 \\
(1.05)\end{array}$ & $\begin{array}{c}1.07 \\
(1.11)\end{array}$ & $\begin{array}{c}1.0 \\
(4.05)\end{array}$ & $\begin{array}{c}1.0 \\
(1.05)\end{array}$ \\
\hline & Missile Criteria & & & $\begin{array}{l}2 \times 4 \text { timber plank } 15 \text { ib @ } \\
50 \text { mph (horiz.): max. } \\
\text { height } 30 \mathrm{ft} \text {. }\end{array}$ & $\begin{array}{l}2 \times 4 \text { timber plank } 15 \mathrm{lb} @ \\
50 \text { mph (horlz.): max. } \\
\text { height } 50 \mathrm{ft} \text {. }\end{array}$ \\
\hline \multirow[b]{4}{*}{$\begin{array}{l}T \\
0 \\
r \\
n \\
a \\
d \\
0\end{array}$} & $\begin{array}{l}\text { Annual Hazard } \\
\text { Probabiliiy } \\
\text { of Exceosance }\end{array}$ & & & $2 \times 10^{-5}$ & $2 \times 10^{-5}$ \\
\hline & Importance Factor & & & $1=1.0$ & $1=1.35$ \\
\hline & APC & & & 40 pst @ 20 pst/sec & $125 \mathrm{pst} @ 50 \mathrm{pst} / \mathrm{sac}$ \\
\hline & Missile Criteria & & & $\begin{array}{l}2 \times 4 \text { timber plank } 15 \text { lb @ } \\
100 \text { mph (horiz.); max. } \\
\text { hoight } 150 \text { ft; } 70 \text { mph (vent) } \\
3 \text { in. dia, std. steel pipe, } 75 \\
\text { lb } @ 50 \text { mph (horiz.); max. } \\
\text { height } 75 \mathrm{~h}, 35 \text { mph (vert.) }\end{array}$ & $\begin{array}{l}2 \times 4 \text { timber plank } 15 \mathrm{lb} @ \\
150 \mathrm{mph} \text { (horiz.), max. } \\
\text { height } 200 \mathrm{t} ; 100 \mathrm{mph} \\
\text { (ven.) } \\
3 \text { in. dia. std. steel pips, } 75 \\
\text { lb @ } 75 \mathrm{mph} \text { (horiz.); max. } \\
\text { height } 100 \mathrm{ft}, 50 \text { mph (ver.) } \\
3,000 \mathrm{lb} \text { automobile @ } 25 \\
\text { mph, rolls and tumbles }\end{array}$ \\
\hline
\end{tabular}

The fis! value cepeesents die importance lacer tor slies 100 miles or more intand. The value in parengesis snould be used at me ocasdine. Lnear

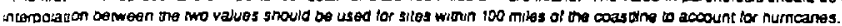

Table 2. Summary of Minimum Wind Design Criteria

hurricanes, and tomadoes are comfained in Table 3. All wind speeds are fastest-mile. Minimum recommended basic wind speeds are also noted in the table.

\section{c. General Use Facidities}

The performance goals for General Use facilities are consistent with objectives of ASCE 7-88 Euilding Class 1. Ordinary Structures. The wind-torce resisting struciural system should not collapse under design load. Survival without collapse implies that occupants should be able to find an area of relative safety inside the building. Breach of the building envelope is acceptable, since continement is not essential. Flow of air through the building and water damage are acceptable. Severe damage, including total loss, is acceptable, so long as the structure does not collapse.

The ASCE 7.88 standard calls for the basic wind speed to be based on an exceedance probability of 0.02 per year. The importance factor for this class of building is 1.0. For those sites within 100 miles of the Gutf of Mexico or Atfantic coastlines, a slightly higher importance factor is recommended to account for hurricanes.
Terrain surrounding the facilities should be classified as Exposure B, C. or D, as appiopriate. Gust response factors and velocity pressure exposure factors should be used according to rules of tho ASCE 7-88 procedures.

Wind pressures are calculated on the walls and roots of enclosed buildings by appropriate pressure coefficients specified in the ASCE 7.88 standard. Openings, either of necessity or created by wind forces or missiles, result in internal pressures that can increase wind forces on components and cladding. The worst cases of combined internal and external pressures should ve considered, as required by the standard.

Structures in the General Use category may be designed by either allowable stress design (ASD) or strongth design (SD) as appropriate for the material used in construction. Except when applicable codes provide otherwise, plausible load combinations shall be considered to determine the most unfavorable effect on the building, foundation, or structural member being considered. When using ASD methods, allowable siresses appropriate for the building material shall be 


\begin{tabular}{|c|c|c|c|c|c|c|}
\hline \multirow{3}{*}{ Building Category } & \multicolumn{6}{|c|}{ Fastest-Milo Wind Speeds at $10 \mathrm{~m}$ Height } \\
\hline & \multirow{2}{*}{$\begin{array}{c}\begin{array}{c}\text { General } \\
\text { Use }\end{array} \\
\text { Wind }\end{array}$} & \multirow{2}{*}{$\begin{array}{c}\begin{array}{c}\text { Important } \\
\text { or Low } \\
\text { Hazard }\end{array} \\
\text { Wind }\end{array}$} & \multicolumn{2}{|c|}{ Moderate Hazard } & \multicolumn{2}{|c|}{ High Hazard } \\
\hline & & & Wind & Tornado & Wind & Tornado \\
\hline \multicolumn{7}{|l|}{ DOE PROUECT SITES } \\
\hline Bendix Plant, MO & 72 & 72 & 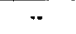 & 144 & - & 144 \\
\hline $\begin{array}{l}\text { Los Alamos Nationai } \\
\text { Laooratory. NM }\end{array}$ & 77 & 77 & 93 & $\cdots$ & 107 & -- \\
\hline Mouno Laboratory, $\mathrm{OH}$ & 73 & 73 & 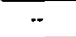 & 136 & - & 136 \\
\hline Pantex Plant. TX & 78 & 78 & + & 132 & $\cdots$ & 132 \\
\hline Rocky Flats Plant, CO & 109 & 109 & 138 & (3) & 161 & (3) \\
\hline $\begin{array}{l}\text { Sandia National Laboratories, } \\
\text { Albuquerque, NM }\end{array}$ & 78 & 78 & 93 & $\cdots$ & 107 & $\cdots$ \\
\hline $\begin{array}{l}\text { Sandia National Laboratones } \\
\text { Livermore. CA }\end{array}$ & 72 & 72 & 96 & $*$ & 113 & $\cdots$ \\
\hline Pinellas Plant, FL & 93 & 93 & 130 & $\cdots$ & 150 & -- \\
\hline Argonne National Laboratory -- East. IL & $70^{(1)}$ & $70^{(1)}$ & $\cdots$ & 142 & $\cdots$ & 142 \\
\hline Argonne National Laborator: -- West, ID & $70^{(1)}$ & $70^{(1)}$ & 83 & -- & 95 & 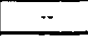 \\
\hline Brooknaven National Laboratory, NY & $70^{(t)}$ & $70^{(1)}$ & $\cdots$ & $95^{(7)}$ & 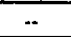 & $95^{(2)}$ \\
\hline Princeton Plasma Physics Laboratory, NJ & $70^{(1)}$ & $70^{(1)}$ & $\dot{*}$ & 103 & - & 103 \\
\hline Idaho National Engineering Laboratory, ID & $70^{(1)}$ & $i 0^{(9)}$ & 84 & $\cdots$ & 95 & - \\
\hline Feed Matenals Production Center. OH & $70^{(1)}$ & $70^{(1)}$ & $\cdots$ & 139 & -- & 139 \\
\hline $\begin{array}{l}\text { Oak Rigge National Laboratory, } X-10 \text {, } \\
K-25 \text {, and } Y-12 \text {, IN }\end{array}$ & $70^{(1)}$ & $70^{(1)}$ & $\bar{\omega}$ & 193 & -- & 113 \\
\hline Paduach Gaseous Diffusion Plant. KY & $70^{(1)}$ & $70^{(1)}$ & $\cdots$ & 144 & $\cdots$ & 144 \\
\hline Portsmouth Gaseous Diffusion Plant. OH & $70^{(1)}$ & $70^{(1)}$ & 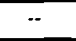 & 110 & 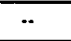 & 110 \\
\hline Nevada Test Site. NV & 72 & 72 & 87 & -- & 100 & $\cdots$ \\
\hline Hantord Project Site, WA & $70^{(1)}$ & $70^{(1)}$ & $80^{(1)}$ & $\because$ & $90^{(1)}$ & 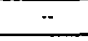 \\
\hline Lawrence Berkeiny Laboratory, CA & 72 & 72 & 95 & 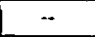 & 111 & $\because$ \\
\hline $\begin{array}{l}\text { Lawrence Livermore National } \\
\text { Laboratory. CA }\end{array}$ & 72 & 72 & 96 & 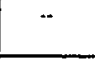 & 113 & $\cdots$ \\
\hline $\begin{array}{l}\text { Lawrence Livermore National } \\
\text { Laboratory. Site } 300 \text {. CA }\end{array}$ & 80 & 80 & 104 & 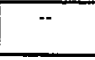 & 125 & $-\cdot$ \\
\hline $\begin{array}{l}\text { Energy Technology and Engineering } \\
\text { Center, CA }\end{array}$ & $70^{(1)}$ & $70^{(1)}$ & $\overline{--}$ & $95^{(2)}$ & 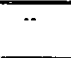 & $95^{(2)}$ \\
\hline Sianford Linear Accelerator Center, CA & 72 & 72 & 95 & $\cdots$ & 112 & 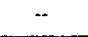 \\
\hline Savannah River Plant, SC & 78 & 78 & $\cdots$ & 137 & $\cdots$ & 137 \\
\hline
\end{tabular}

NOTES:

i1) intimirn exueme wind speed

2) istnimum vornaco spoed.

(3) Almougn extreme winds govern at Rocky Flats. It Is racommended that taclides be designed tor the comaco missile gntena. APC noed not be consudered.

Table 3. Recommended Basie Wind Speeds for DOE Siles. 
used with the following combinations that involve wind:

(a) $\mathrm{DL}+\mathrm{W}$

(b) $0.75(D L+W+L L)$

where

$$
\begin{aligned}
& O L=\text { dead load } \\
& L L=\text { live load } \\
& W=\text { wind load }
\end{aligned}
$$

When using SD methods, the following load combinations inat involve wind are recommended:
(a) $0.9 \mathrm{DL}+1.3 \mathrm{~W}$
(b) $1.2 \mathrm{DL}+0.5 \mathrm{LL}+1.3 \mathrm{~W}$

The SD method requires that the strength provided be greater than or equal to the strength required to carry the factored loads. Appropriate strength reduction factors must be applied to the nominal str ength of the material being used.

\section{d. Imporart or Low Hazard Facilities}

Important or Low Hazard facilities are equivalent to essential faciities (Class II), as detined in ASCE 7-88. The structure's main wind-force resisting structural systems shall not collapse at design wind speeds. Complete integrity of the building envelope is not required because no significant quantities of toxic or radioactive materials are present. However, breach of the building envelope may not be acceptable if wind or water interfere with the facility function. If loss of facility function is caused by water damage to sensitive equipment, collapsed interior partitions, or excessive damage to HVAC ducts and equipment, then loss $\mathrm{ct}$ cladding and missile pertoration at the design wind speeds must be prevented.

An annual wind speed exceedance probability of 0.02 is specified. but the importance factor for important or Low Hazard category structures is 1.07. For those sites located within 100 miles of the Gulf of Mexico or Atlantic coastines, a slightly higher importance factor is used to account for hurricane winds.

Once the design wind speeds are established and the importance factors applied. the cetermination of wind loads on Important or Low Hazard categony structures is identical to that described for General Use category s:ructures. Facilities in this category may be designed by $A S D$ or SD methods, as appropriate, for the construction material. The load combinations described for General Use structures are the same tor Important or Low Hazard structures. However, greater attention should be paid to connections and anchorages for main members and components, such that the integrity of the structure is maintained, see (McDonald, 1988).

\section{e. Moderate Hazard Facilities}

The pertormance goal for Moderate Hazard facilities requires more rigorous criteria than is provided by standard building codes. For some DOE sites. tomadoes must be considered.

\section{Extreme Winds and Hurricanes}

For those sites where tornadoes are not a viable threat. the recommended basic wind speed is based on an annual exceedance probability of $1 \times 10^{-3}$. The importance factor is 1.0. For those sites located within 100 miles of the Gulf of Mexico or Atlantic coastlines, a slightly higher importance factor is specified to account for hurricanes.

Once the basic wind speeds are established and the importance factors applied, determination of Moderate Hazard category wind loads is identical to that described for the General Use category. Facilities in this category may be designed by ASD or SD methods, as appropriate, for the material being used in construction. Plausible load combinations shall be considered to determine the most unfavorable effect on the building, foundation, or structural member being considered. When using ASD, ailowable stresses appropriate for the building material shall be used with the following wind load combinations:

(a) $0.9(D L+W)$

(b) $0.67(D L+W+L L)$

The SD load combinations recommended for the Moderate Hazard category are:

(a) $\mathrm{DL}+1.3 \mathrm{~W}$

(b) $1.1 \mathrm{DL}+0.5 \mathrm{LL}+1.2 \mathrm{~W}$

Greater attention should be paid to connections and anchorages for main members and components, such that the integrity of the structure is maintained, see (McDonald, 1988).

A minimum missile criteria is specified to account for objects or debris that could be picked up by extreme winds, hurricane winds, or weak tornadoes. A $2 \times 4$-in. timber plank weighing $15 \mathrm{lbs}$. is the specified missile. Its impact speed is $50 \mathrm{mph}$ at a maximum height of 30 it above ground level. The missile will break glass; it will perforate sheet metal siding, wood siding up to $3 / 4$ in. thick, or form board. The missile could pass through a window or a weak exterior wall and cause personal injury or damage to interior contents of a building. The specified missile will not pertorate unreirtorced masonry or brick veneer walls or other more substantial walls. 


\section{Tornadoes}

For those sites requiring design for tornadoes, the cnteria are based on site-specific studies. The basic wind speed is associated with an annual hazard probabilit of exceedance of $2 \times 10^{-5}$. The wind speed oblained from the tornado hazard model is converted to fastest-mile. The imponance factor for the Moderate Hazard category is 1.0 .

With the wind speed converted to fastest-mile wind and an importance factor of 1.0 . equations in the ASCE standard should be used 10 obtain design wind pressures on the structure. Exposuie Category $C$ should aiways be used with tornado winds regardless of the actual terrain roughness. The veiocity pressure exposure coefficient and the gust response factor are abtained from appropriate tables in the AUCE standard External pressure coetficients are used to obtain tornado wind pressures on various surfaces of the structure. A distinction is made between the main wind-force resisting system and components and cladding.

If the building is not specitically sealed to maintain an internal negative pressure for confinement of hazardous miaterials, or, if openings greater than one square toot per 1000 cubic foot of volume are present, or, if openings of this size can be created by missile perforation, then the effects of internal pressure should be considered according to ASCE procedures. It the building is sealed, then atmospheric pressure change (APC) pressures associated with the tornado should be considered.

$A P C$ pressure is half its maximum value $: t$ the radius of maximum wind speed in a tomado. Thus, critical tornado loading will be one-half the maximum APC pressure plus the maximum tornado wind pressure. A loading condition of APC alone can occur on the roof of a buried tank or sand fitter, it the root is exposed al the ground surface. APC pressure always acts outward. The effect of rate of pressure change on ventilation systems should be analyzed to assure that it does not interrupt any function or processes carried out in the lacility. Procedures and computer codes are available for such analyses.

Plausible load combinations shall be considered to determine the most unfavorable effect on the building. foundation. or structural member being considered. When using ASO methods, allowable stresses appropriate for the building materials shall be used with the following load combinations that involve tornado loading.
(a) $0.75\left(\mathrm{DL}+\mathrm{W}_{\mathrm{t}}\right)$
(b) $0.625\left(\mathrm{DL}+W_{1}+\mathrm{LL}\right)$

The so load combinations recommended for the Moderate Hazard category are:
(a) $\mathrm{DL}+\mathrm{W}_{\mathrm{t}}$
(b) $\mathrm{DL}+L L+W_{t}$

where

$$
\begin{aligned}
& W_{t}=\text { tornado loading, including } A P C \text {, as } \\
& \text { appropnate. }
\end{aligned}
$$

Two missiles are specified as minimum criteria for this usage category. The $2 \times 4$-in. timber plank weighing 15 lbs. is assumed io travel in a horizontal direction at a speed up to $100 \mathrm{mon}$. The horizontal speed is effective up to a height of $150 \mathrm{ft}$ above ground level. If carried to a great height by the tornado winds, the timber plank could achieve a terminal vertical speed of $70 \mathrm{mph}$ in fatling to the ground. The horizontal and vertical speeds are assumed to be uncoupled and they should not be combined. The missile will pertorate most conventional wall and roof cladding except reinforced masonry or concrete. The cells of concrete masonry walls must be tilled with grout to prevent pertoration by the timber missile. The second missilu is a 3-iil. diameter standard steel pipe, which weighs 75 Ibs. It can achieve a horizontal impact speed of $50 \mathrm{mph}$ and a vertical speed of $35 \mathrm{mph}$. Its horizontal speed could be effective 10 heights of $75 \mathrm{ft}$ above ground level. The missile will perforate conventional metal siding, sandwich panels, wood and metal decking on roots, and gypsum paneis. In addition, it will pertorate unreinforced concrele masonry and brick veneer walls, reintorced concrete masonry walls less than 8 in. thick, and reinforced concrete walls less than 6 in. thicls. Afthough wind pressure, APC, and missile impact loads can act simultaneously in a tornado, the missile impact loads can be treated independently for design and evaluation purposes.

\section{High Hazard Facilities}

The performance goal can be achieved for this category if the main wind-force resisfing members do not collapse, structurai components do not fail, and the building envelope is not breached at the design wind loads. Loss of cladding, broken windows, collapsed doors, or significant missile perforations must be prevented. Strong air flow through the building or water damage cannot be tolerated.

\section{Extreme Winds and Huricanes}

For those sites that do not require specific design for tornado resistance, the recommended basic wind speed is based on an annual hazard exceedance probability of $1 \times 10^{-4}$. The importance tactor is 1.0 . The wind speed is tastest-mile at an anemometer height of 10 meters above ground leves. 
Once the basic wind speeds are established and the importance factors applied, determinatio:l of High Hazard facility wind loads is identical to that described for the General Use category. Facilities in this category may be designed by ASD or SD methods, as appropriate, for the material being used in construction. Recommended wind load combinations are the same as for Moderale Hazard facilities. Greater aftention should be paid to connections ano anchorages for main members and componemis, such that the integrity of the structure is maintained, see (McDonald, 1988).

The missile criteria is the saine as for the Moderate Hazard category, except that the maximum height achieved by the missile is $50 \mathrm{ft}$, instead of $30 \mathrm{tt}$.

\section{Tornadoes}

For those sites requiring design for tornado resistance. the criteria is based on site-specitic studies. The recommended basic wind speed is associated with an annual hazard probability of exceedance of $2 \times 10^{-5}$ (the same as the Moderate Hazard category). The wind speed obtained from the tornado hazard model is converted to tastest-mile. The impontance tactor for the High Hazard category is 1.35 .

With the wind speed expressed as fastest-mile and an importance factor of 1.35. ASCE $7-B 8$ equations should be used to obtain design wind pressures on the structure. Exposure Category $\mathrm{C}$ should always be used with tornado winds regardless of actual terrain roughness. The velocity pressure exposure coefficient and the gust response factor are obtained from appropriate tables in the ASCE standard. External pressure coefficients are used to obtain tornado wind pressures on various suriaces of the structure. A distinction is made between the main wind-force resisting system and ccmponents and cladding in determiring wind pressuies.

II the building is sealed to confine hazardous materials, the wind and APC load combinations specitied for the Moderate Hazard usage category also should be used lor this category. The effects of rate of pressure change on ventilating systems should be analyzed. Recommended tornado wind load combinations for Moderate Hazard facilities also apply to High Hazard tacilities.

Three missiles are specified as minimum criteria for this usage category. The $2 \times 4$-in. timber plank weighs 15 lbs. is assumed to travel in a horizontal direstion at speeds up to $150 \mathrm{mph}$. The horizontal missile is effective to a maximum height of $20 \mathrm{n} \mathrm{ft}$ above ground level. If carnied to a great height $b_{\text {; }}$ 'he tomado winds, it could achieve a terminal speed in the vertical direction of $100 \mathrm{mph}$. The horizontal and vertical speeds are uncoupled and should not be combined. The missile wil perforate most conventional wall and root cladding except reinforced masonry and concrete. Each sell of the concrete masonry shall contain a $1 / 2$-in.-diameter rebar and be grouted to prevent pertoration by the missile. The second missile is a 3-in.-diameter standard steel pipe, which weighs 75 lbs. II can achieve a horizomal impact speed of $75 \mathrm{mph}$ and a vertical speed of $50 \mathrm{mph}$. The horizontal speed could be effective at heights up to $100 \mathrm{ft}$ above ground level. This missile will periorate unreinforced concrete masonny and brick veneer walls, reinforced concrete masonry valls less than 12 in. thick, and reinforced concrete walls less than 8 in. thick. The third missile is a $3000-16$ automobile that is assumed to roll and tumble on the ground and achieve an impact speed of $25 \mathrm{mph}$. Impact of an automobile can cause excessive structural response to columns, walls, and trames. Impact analyses should be pertormed to determine specific effects. Collapes of columns, walls, or trames may lead to turther prograssive collapse.

\section{Tomado Missile impact Tests}

Wall barrier specimens have been tested at the Tornado Missile Impact Facility at Texas Tech University. The facility has an air activated tornado missile cannon capable of tiring $2 \times 4$ timer planks weighing 12 pounds up to $150 \mathrm{mph}$ and 3 in. dia. steel pipes weighing 75 pounds at speeds to $75 \mathrm{mph}$.

Wall barriers tested to date include reinforced concrete walls from 4 in. to $10 \mathrm{in}$. thick; 8 in. and $12 \mathrm{in}$. walls of reinforced Concrete Masonry Units (CMU); and two other masonry wall configurations consisting of an 8 in. CMU and 4 in. clay brick veneer; and a 10 in. composite wall having two wythes of 4 in. clay brick.

The impact tests series was designed to determine the impact speed to produce backtace spall of each wall barrier. A set of 15 wall sections have been constructed and tested at this time. Prefiminary findings suggest that all cells of CMU walls must be grouted to prevent missile penetration. Results of these impact test as well as previous available test data will be compared with existing impact formulas. In particular, the Rotz Equation and the Modilied NDRC formula are being examined. A new impact formula for CMU walls is being developed. Resulls of this study are being assembled into a report which should be available in summer 1991.

\section{h. Comments on Load Combinations}

The ratios of hazard probabilities 10 periormance goal probar iitities for the usage categories as shown in Table 4 are a.1 approximate measure of the conservatism required in the design to achieve the performance goals. The most conservatism is needed in the response evaluation and acceptance criteria for design 
of General Use and Imponani or Low Hazard tacilities. Scmewhat less conservatism is necded tor Mocierare and High Hazard facilities. The hazaro protabilities specified for tornadoes are less than tne pertormance goal probabilities. Hence. the pertormance goals are theoretically met with no adided conservatism in ine design.

Conservaíism can be achieved in designs by specirying lactors of safety tor Allowable Stress Design (ASD) and load factors for Strength Design (SD). Consistent with the ratios in Table 4 , the loading conditions recommended for design for DOE lacilities are summanzed in Tálile 5. plants as given in ACI 349 for concrete and ANSI/AISC N690 (AISC, 1984)for steel.

Acditional background material on wind and tornado effects can oe found in (McDonaid. 1985a; MCDonaid. 1985b). A commentary on the designn criteria summanized there is also included in Appendix ${ }^{P}$ of (Kennedy et al. 1990).

\section{Summary and Conclusions}

IJCRL-15910 is sn example of deterministic design/evaluation criteria developed to achieve

\begin{tabular}{|c|c|c|c|}
\hline Usag: Category & Periormance Goals & $\begin{array}{l}\text { Wind/Tornaco } \\
\text { Hazaro Probability }\end{array}$ & $\begin{array}{c}\text { Ratio of Hazard Probabulity } \\
\text { to Perlormance Goal }\end{array}$ \\
\hline $\begin{array}{l}\text { Exureme Winds } \\
\text { General Use } \\
\text { Imiportünt cr Low Hazard } \\
\text { Moderate Hazato } \\
\text { High Hazard } \\
\text { Iernadoes } \\
\text { Moderate Hazard } \\
\text { High Hazard }\end{array}$ & $\begin{array}{r}10.3 \\
5 \times 10.4 \\
10.4 \\
10.5 \\
\\
10.4 \\
10.5\end{array}$ & $\begin{array}{l}2 \times 10^{-2} \\
10^{-2(1)} \\
10^{-3} \\
10^{-4} \\
2 \times 10^{-5} \\
3 \times 10^{-6(2)}\end{array}$ & $\begin{array}{l}20 \\
20 \\
10 \\
10 \\
<1 \\
<1\end{array}$ \\
\hline
\end{tabular}

(1) $2 \times 10^{-2}$ with $1=1.07-10^{-2}$

(2) $2 \times 10^{-5}$ with $I=1.35-3 \times 10^{-6}$

Table 4. Patio of Hazard Probability to Performance Goal

Since the ratio of extreme wind hazard probability to pertormance goal probability for General Use and important or Low Hazard facilites are the largest, 20. designs for these categories should be the most conservative in terms of lactors of safely for ASD and load factors $S D$. The recommended combinations are essentially those given in ASCE 7-88. (ASCE, 1990). The recommended loan combination for Moderate and High Hazard tacilities are slightly les's conservative than for the General Use and Important or Low Hazard categories. because the ratio of extreme wind hazard probability to performance goal probat ility is less $\{i i$, The load factor soefficients have been reduced by approximately 10 percent.

The tornado hazard protakilities for both Moderate and High Hazard facilities are less than the periormance goat probabilities. The tornado load combinations tor both $A S D$ and $S D$ recognize that the performance goais dre thenretically met and no added conservatism in the load combination is required. This approach is onsisterit with criteria for commercial nuclear power
Frovat iistic periormance goals. UCRL -15310 also covers seisrinic and flood as well as wind and tornado criteria as tiscussed in this paper. The criteria doveloped is consisiem with thie consensus standard ASCE $7-88$ and required by DOE General Design Criteria, 'DOE, 1989). Coriservatism is specified which is sutficient to achieve ine performa.tce goals. This conservatism increases from jeriaral use to high hazard usage category.

The UCRL-15910 wind/tornado design and evaluation guidelines follow the philosophy of: (1) graduat reduction in hazard annual exceedance probabilits; and (2) gradual increase in conservatism of evaluation procedure as one goes from a Generat Use to a High Hazard facility. Four separate sets of designevaluation criteria have been presented in UCPL-15910, each with a different periormance goal. In all these criteria. loading is selected from hazard curves on a probabilistic basis but response evaluation methods and acceptable behavior limits are deterministic approaches witi whicht design engineers are tamiliar. 


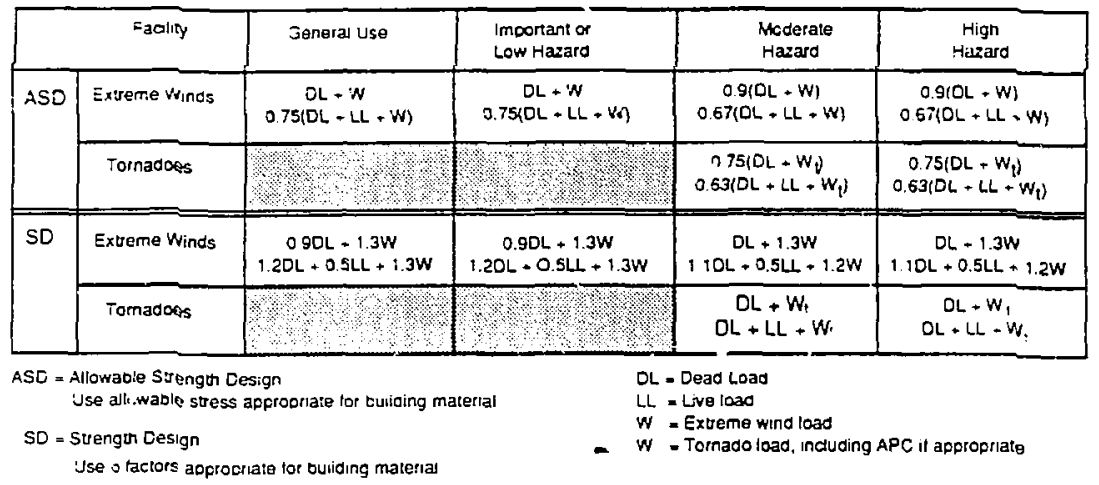

Táble 5. Summary of recommended wind and tomado load combinaticns.

\section{References}

American Concrete instrite, 1985: Code Requirements for Nuclear Safety-Related Concrete Structures (A.Cl 349-85) and Commentary- $\mathrm{ACl}$ 349R-85. Detroit, Michigan.

American instrure of Steol Construction. Inc. 1984: Nuclear Facilities-Steel Salty-Rela:ed Structuring tor Design, Faorication. and Erection. ANSI/AISC N69O, Chicago. Illinois.

ASCE. 1990: Minimum Design Loads for Buildirg and Other Siruc:ures, ASCE 7.88 iformerty ANSI A58.1\%. American Society of Civit Engingers.

Coats. D.W. and R.C. Murray, : $\$ 5$ : Natural Phenomena Hazaros Meceling Prbject: Extreme Wind/Tornado Hazard Models for Deparment of Energy Sites. Lawrence Livermoro National Laboratory. Report UCAL-53526 Rev. $?$.

DOE. : 989: U.S. Deparment of Energy. Genere! Design Criteria, DOE Ord " $130.1 \mathrm{~A}$. Washington, D.C.

EPRI, 1990: Advariced Light Water Reactor Requirements Document. Volume 1. AlWR Poiry and Summary of Top-Tier Fecurants. Final Drait for Reviow. Eiectric Power Fesearch Instituie, Pal= Alto, Calitornia.

ICBO. :988: Uniturm Buiding Code 1988 Edition. Internaticnal Conierance of Euilding Otticials. Whitter. Sartorna.
Kennedy. R.P., S.A. Short, J.R. MeDonaid, M.W. McCann, R.C. Murray, and J.F. Hill, 1990: Design anq Evaluation Guidelines For Department of Energy Facilities Subjected to Natural Phenorrena Hazards, Lawrence Livermore National Laboratory, Report UCFL-15910.

Kimura, C. Y. and R. J. Budnitz, 1987: Evaluation of External Hazards to Nucleat Power Plants in the United States. NUREGJCR.5042, Lawrence Livermore National Laboratory. Repor LCID-21223.

McDonald, J.R., 1985a: Extreme Winds and Tornadoes: An Overview, Lawrence Liveemore National Laboratory, Report UCRL-15745.

McDonald, J.R., 1985b: Exireme Winds and Tornartoes: Design and Evaluation of Buildings and Structures, Lawrence Livermore National Laboratory. Report UCRL-15747.

McDonaid, J.R., 1988: Structural Details for Wind Design. Lawrence Livermore National Laboratory. Report UCRL-2113!.

NRC, 1974: Regulatory Gulce 1.76. U.S. Nuclear Regulatory Commission, Wasningion, D.C.

Ravindra, M. K. and A. M. Natday, 1990: State-ot-the-An and Current Research Activities in Extreme Winds Relatieg to Design ano Evaluation of Nuclear Power Plan B. NUREG'CR. 5497 . 